\title{
THE DIMENSIONS OF GREEN SUPPLY CHAIN MANAGEMENT PRACTICES
}

\author{
R.A.D.Dillanjani Weeratunge ${ }^{1}$ and Renuka Herath ${ }^{2}$ \\ ${ }^{1}$ University of Kelaniya \\ ${ }^{2}$ Department of Marketing Management, University of Kelaniya
}

\begin{abstract}
Green Supply Chain Management (GSCM) has become known as a key approach to enhance the environmental sustainability. GSCM has also been receiving the spotlight in many studies. In this era, preserving the natural environmental has become very challenging so that business organizations have started to feel the pressure of increased awareness level of environmental protection by the society.
\end{abstract}

This paper therefore is intended to provide a critical evaluation of literature review on Green Supply Chain Management Practices. A rigorous literature review was carried out in order to critically evaluate the definitions and different Green supply chain management practices discussed by many authors. Both conceptual and empirical papers published in past years in the reputed journals were chosen for the review. Then a content analysis was carried out comparing and contrasting the theories presented and discussed in the chosen articles published on Green management practices. Green Procurement, Green Design and Manufacturing, Green Distribution, Reverse Logistics were the identified dimensions of Green Supply Chain Management.

Keywords: Green Supply Chain Management Practices, Green Procurement, Green Design and Manufacturing, Green Distribution, Reverse Logistics

\section{Introduction}

Supply Chain Management (SCM) is the integration and coordination of business processes and strategy throughout a supply chain procedure finally for the satisfaction of end consumer. In the past, manufacturing industries were not much concerned nor persecuted on their environmental hazardous practices. Nowadays however, most manufacturing companies have been changing to eco-friendly activities to avoid environmental pollution and also to meet the customer demand for more environment friendly products. In present, organizations are shrinking in the red ocean to find new businesses. They have to find new strategies to retain the existing business due to competitiveness in the market. As a result, most organizations adopt the Green Supply Chain Management (GSCM) practices to retain the current businesses whilst trying to find methods to increase their organizational sustainability. Green Supply Chain Management follow the practices of free air pollution and methods of environment friendly waste disposals. Currently, there have been noticeable increase of continuing practices and implementing new rules and regulations to enhance the green environment in the society. The speedy global industrialization has contributed towards the damaging of the ozone layer and rapid melting of Antarctic icebergs- both of which could lead to cataclysmic consequences. The substantial increase of such issues has created the human demand to force the manufacturers to adhere to more eco-friendly practices. The effect of more pressure urges the firms to give prominence to run today's businesses on a more customer-pull mode than the customer-push status they enjoyed earlier. Today, organizations are shrinking their profit margins, implementing environment friendly practices, reducing the carbon air pollution throughout the supply chain while offering competitive prices. The concept of Green Supply Chain Management creates a new empirical approach to win the competitive advantage in the business world. Most organizations adopt the Green Supply chain management practices thus helping to enhance the quality of human living standards and increasing the expectations of reduced health hazards whilst winning the consumer's mind in the process. 


\section{Aim of the paper}

This paper is based on the evaluation of literature review of Green Supply Chain Management Practices analysed and highlighted in many authors in different research papers. It's undeniable that new technological changes, innovations and global economic developments will change the organizational performance substantially as we proceed into the future. The future of organizational sustainability is balancing on the green material and the environmental friendly production in their supply chains. Today manufacturing companies are effectively changing to the green supply chain because the changing of business environment demand it. It has posed the companies to balance cost reduction and the profit growth. With the ever rising competition coupled with the imposing new environmental rules in the business world, manufacturing companies are struggling to maintain their market share. Nowadays, the green environment has become a popular topic and most organizations consider it to be paramount to be aware of economic and ecological impact on their businesses. The aim of this paper therefore is to evaluate the concept of Green Supply Chain Management to identify the different dimensions of it.

\section{Design \& Methodology}

The literature written on Green Supply Chain Management was carefully selected to review for the purpose of this study. The articles written on Green Supply Chain Management during last five years only on the reputed journals such as Emerald International Journal (Emerald), International Journal of Managing Value and Supply Chains (IJMVSC), International Institute for Science, Technology and Education (IISTE), International Journal of Economics, Finance and Management Science (SciencePG), International Journal of Environmental Monitoring and Protection (Open Science), Journal Sustainability (MDPI), International Journal of Management \& business studies were selected. The key words of Green Supply Chain and sustainable supply chains were used to filter the articles. The selected papers were read many times to identify the different dimensions of Green Supply Chain Management. More than 35 papers were downloaded and read by the authors. When one theme was identified and highlighted by a few articles, the rest of the articles were then reviewed to see whether same theme can be evident or any other can be evident. In the same way as new themes were identified the rest of the articles were again reviewed to ensure whether the evident for the identified dimensions were found out.

\section{Green Supply Chain Management Practices}

Today, environmental issues are increasing due to high demand of eco-friendly products from worldwide consumers. Organizations are forced to introduce Green management practices in their operations to obtain an economic growth. Due to rapid changes in the global manufacturing industry, environmental issues become more prominent to continue the business.

Shultz and Holbrook (1999), stated that the facing of regulatory and community pressures with competitiveness, the importance of organizations to be balance the economic and environmental performance. Lewis and Gretsakis, (2001); Sarkis, 1995, (2001) highlighted that organizations has to introduce strategies to overcome the environmental impact on their products due the increased pressure on environmental sustainability. Introduction of environmental friendly practices may create new opportunities for competitiveness and add value to the core businesses (Hansmann and Claudia, 2001).

The approaches of cleaner production, eco efficiency and environmental management systems have implemented the Green Management Practice. Risk management, regulatory compliance, and business efficiency are the identified factors by Confederation of British Industries (CBI) in 1994 for driving the competitive advantage through the environmental performance. Environmental impacts occur at all stages of a product's life cycle. GSCM has shown the new model for organizations achieve profits and market share objectives by reducing their environmental risks and raising their performance (Van Hock and Erasumas 2000).

The appropriate development of the GSCM concepts and practices may indeed aid the country by showing the environmental burden of both manufacture and disposal of products while even potentially improving the economic positioning. 
Srivastava (2007) stated that Green Supply Chain Management is a root of both environmental management and supply chain management. The contribution of green component enhances the relationship among the supply chain management practices and natural environment.

Hevani et al., (2005) describe that supply chain management is a complex network including coordination and management activities involving in to deliver a finished product to the end customer. It involves various business activities such as sourcing raw materials, manufacturing and assembling parts, storing, distributing and final delivery to the customer. The Globalization, customer expectation, information technology, government regulation, competition and the environment are the influence factors in successful supply chain management. And also further explained about the corporate performance measurement and its applications giving the example that when companies measuring the performance consider the existing financial measures such as return on investment, profitability and revenue with market share.

Hevani et al., (2005) defined the GSCM as adding the "Green" component to the supply chain management influence the relationship of supply chain management to the natural environment and construct the following formula of GSCM.

Green Supply Chain Management $(\mathrm{GSCM})=$ Green Purchasing+Green Manufacturing/ Material Management +Green Distribution/Marketing + Reverse Logistics.

The literature review explained the major elements in GSCM and organizational internal responsibilities with regard to the environmental performance. Several techniques such as life cycle assessment, product stewardship and design for environment principals help managers to map the environmental impact on supply chain. Also explained is that life cycle assessment is a structural approach to define and evaluate the total environmental service incorporate with development of an inventory of data, impact of materials, product and processes and improvement of analysis aspects.

Hevani et al., (2005) identified the Green supply chain management tools and major boundaries such as external pressure and internal pressure associated with managing the Green Supply chain management and performance measurement system. Outcome of the results are discussed. Another popular tool identified in the corporate performance management literature is the "Balanced Scorecard". It is suggested that organizational performance should be viewed from four perspectives such as the learning and growth perspective, the business process perspective, the customer perspective and financial perspective.

The final outcome of the paper is Strategic level support is needed when providing financial support to overcome internal pressure. They discussed external communications, internal improvements and regulatory compliance being the measuring factors of Green supply chain management practices on organizational performance management. 


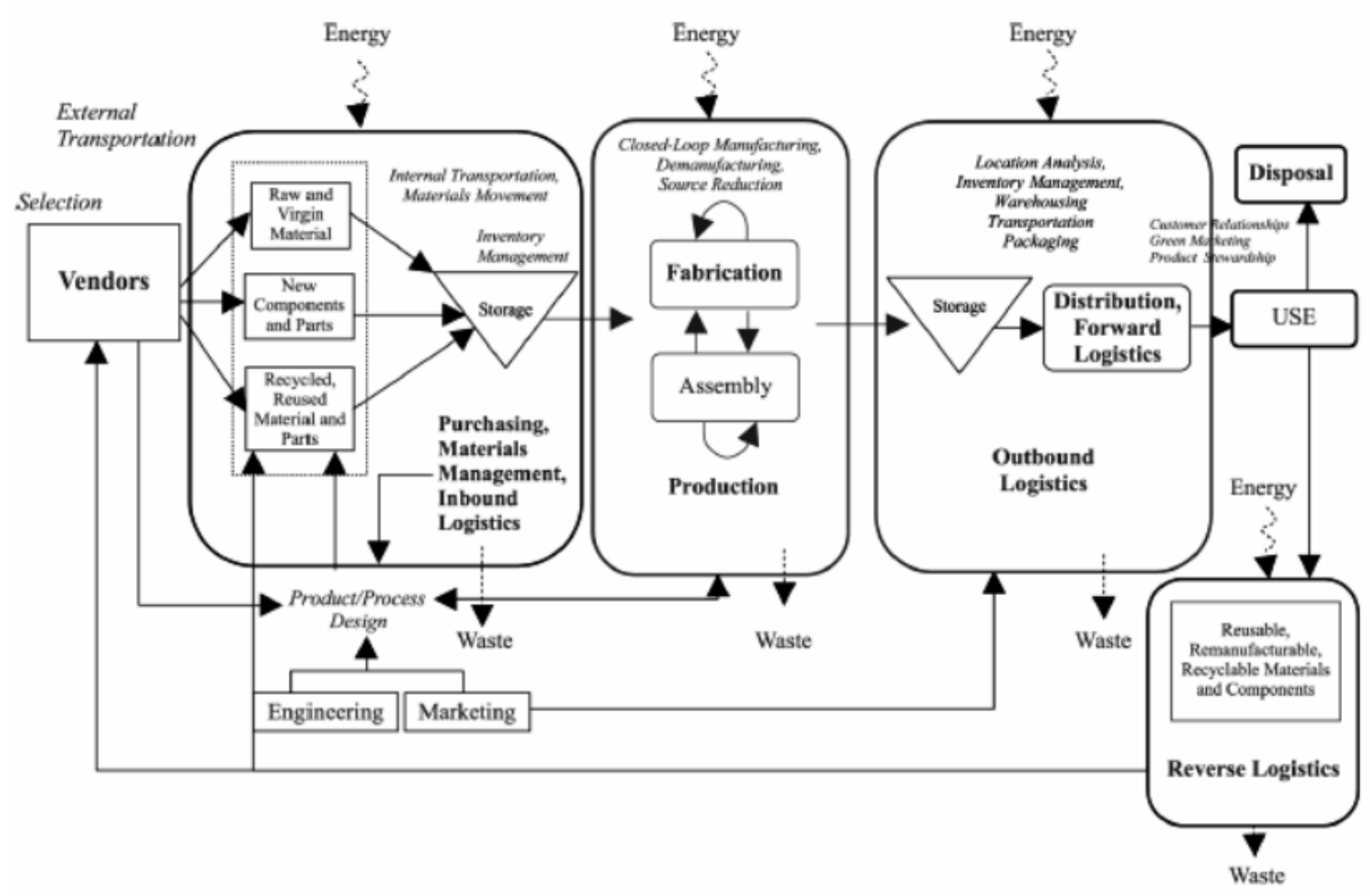

Figure 1. Graph of the GSCM (Hervani et al., 2005

\section{Components of the Green Supply Chain Management}

Figure 1 highlights the a few components of Green Supply Chain Management; Green Procurement, Green Design and Manufacturing and Green Distribution and Reverse Logistics.

\section{Green Procurement}

Green Procurement can be defined as a set of practices followed by an organization to select suppliers who are practicing the eco-friendly methods when manufacturing goods. Manufacturing organizations are compelled to select suppliers who are having environmental competence, technical and eco design capability, environmental performance, ability to develop environmentally friendly goods and ability to support focal organizations eco- friendly objectives. The $3 \mathrm{R}$ uses in green procurement are Reuse, Recycle and Reduce in the process of green procurement in terms of placing orders through email, use eco labelling of products, ensure suppliers' environmental compliance certification and conducting audits on suppliers' internal environmental management are also studied by (Chin et., al 2015)

\section{Green Design and Manufacturing}

Srivastava (2007) stated that the life cycle assessment/analysis and environmentally conscious design of the product explain in the literature. A hierarchic framework for environmentally conscious designs are presented by Madu et al., (2002). Green manufacturing is a very important area in green supply chain operation. Three related fields of study to reduce the use of virgin materials are pinch analysis (Linhoff 1993), and energy and lifecycle analysis (Lee et al., 1995).

\section{Green Distribution and Reverse Logistics}

Reverse logistics practices are different from traditional logistics practices. Green distribution consist of Green packaging and green logistics. Packaging characteristics gives an impact on distribution. Better packages help to rearrange the loading patterns can reduce the material usage and 
increase the warehouse space and reduce the double handling (Carter and Ellram, 1998).

Sarkis (2011), provide a framework to understand and help advance the field of Green Supply Chain Management and its relationship in various research streams. These frameworks explain the issues faced by green supply chains when using the boundaries and the flows of the system. In general overview, supply chain is described with upstream, downstream and internal organizational activities. Explain the relationship of purchasing and procurement functions and flows of upstream activities including the topics of outsourcing, vendor auditing, management and selection, supplier collaboration and supplier development. The Traditional purchasing discipline is enhanced by the upstream activities of supply chain management which can be expanded to have greening components. Traditional production and operations management are related with Internal organizational supply chain activities in the organizations. The activities such as research and design, quality, inventory material and technology management influence the environmental behaviours in the organizations. Outbound logistics and transportation, marketing, distribution, packaging and warehousing are called as downstream flows and relationships utilised by individual consumers or commercial customers. The reverse supply chain explain the activities of recycling, remanufacturing, reclamation and reverse logistics which are related to the closing of the supply chain loop.

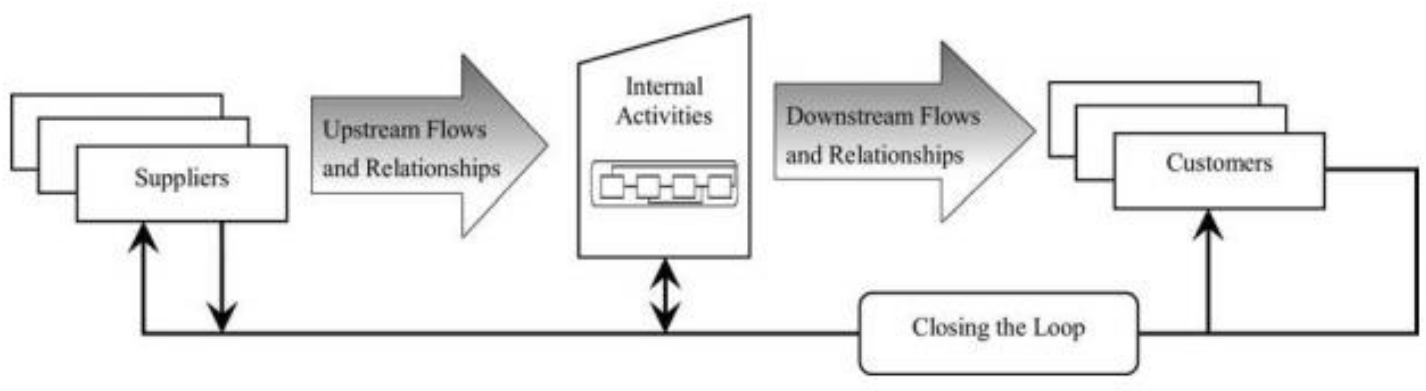

Figure 2. A green Supply Chain diagram with Stages and relationship (Sarkis, 2011)

Table 1 shows the Definitions of the Theoretical Model constructed by Kenneth et al., (2012),Internal Environment Management \& Green Information System are moderated by Green Purchasing, Corporation with customers, Eco-design and Investment Recovery with mediating effect of
Environmental Performance, Operational Performance and economic performance leading to measuring the organizational performance.

Table 1. Construct Definitions (Kenneth W. Green Fr et al, 2012)

\begin{tabular}{|l|l|}
\hline Construct & Definition \\
\hline Internal Environmental Management & $\begin{array}{l}\text { Internal environmental management is the practice of } \\
\text { developing green supply chain management as a strategic } \\
\text { organizational imperative through commitment and } \\
\text { support of the imperative from senior and mid-level } \\
\text { managers (Zhu et al., 2008a) }\end{array}$ \\
\hline Green Information systems & $\begin{array}{l}\text { Green Information systems are information systems that } \\
\text { have been modified and are used to monitor } \\
\text { environmental practices and outcomes (Esty and Winston, } \\
\text { 2006) }\end{array}$ \\
\hline Green Purchasing & $\begin{array}{l}\text { Green purchasing focuses on cooperating with suppliers } \\
\text { for the purpose of developing products that are } \\
\text { environmentally sustainable (Zhu et al., 2008a;carter and }\end{array}$ \\
\hline
\end{tabular}




\begin{tabular}{|l|l|}
\hline & carter, 1998) \\
\hline Cooperation with customers & $\begin{array}{l}\text { Cooperation with customers requires working with } \\
\text { customers to design cleaner production processes that } \\
\text { produce environmentally sustainable products with green } \\
\text { packaging (Zhu et al.,2008a) }\end{array}$ \\
\hline Eco Design & $\begin{array}{l}\text { Eco-design requires that manufacturers design products } \\
\text { that minimize consumption of materials and energy that } \\
\text { facilitate the reuse, recycle and recovery of component } \\
\text { material and parts and that avoid or reduce the use of } \\
\text { hazardous products within the manufacturing process } \\
\text { (Zhu et al., 2008a) }\end{array}$ \\
\hline Investment recovery & $\begin{array}{l}\text { Investment recovery requires the sale of excess } \\
\text { inventories, scrap and used materials and excess capital } \\
\text { equipment (Zhu et al., 2008a) }\end{array}$ \\
\hline Environmental Performance & $\begin{array}{l}\text { Environmental performance relates the ability of } \\
\text { manufacturing plants to reduce air emissions, effluent } \\
\text { waste and solid wastes and the ability to decrease } \\
\text { consumption of hazardous and toxic materials (Zhu et al., } \\
\text { 2008a) }\end{array}$ \\
\hline Economic performance & $\begin{array}{l}\text { Economic performance relates to the manufacturing } \\
\text { plant's ability to reduce costs associated with purchased } \\
\text { materials, energy consumption, waste treatment, waste } \\
\text { discharge and fines for environmental accidents (Zhu et } \\
\text { al., 2008a) }\end{array}$ \\
\hline Operational Performance & $\begin{array}{l}\text { Operational performance relates to the manufacturing } \\
\text { plant's capabilities to more efficiently produce and deliver } \\
\text { products to customers (Zhu et al., 2008a) }\end{array}$ \\
\hline Finational Performance & $\begin{array}{l}\text { Financial and marketing of the organization as compared } \\
\text { to the industry average (Green and Inman, 2005) }\end{array}$ \\
\hline & \\
\hline
\end{tabular}

Their findings make a logical sense of the relationship among the performance constructs seem to be leverage of environmental performance and economic performance has improved operational performance which leads to improve the organizational performance.

Bjorklundet. al., (2012) identified the five dimensions in the framework developed by Caplice and Sheffi (1995) and developed further as shown in table 2 for the review of their paper. They are mentioned in table 2 and explained later;
Table 2: Framework Dimensions

\begin{tabular}{|c|c|}
\hline Caplice and Sheffi (1995) & Bjorklund et. al., (2012) \\
\hline Comprehensive & Stakeholder perspective \\
\hline Causally Oriented & $\begin{array}{c}\text { The Purpose of } \\
\text { measuring }\end{array}$ \\
\hline Vertically integrated & $\begin{array}{c}\text { Managerial levels of } \\
\text { measuring }\end{array}$ \\
\hline Horizontally integrated & $\begin{array}{c}\text { Measuring across the } \\
\text { supply chain } \\
\text { Combination of } \\
\text { measurements }\end{array}$ \\
\hline Internally comparable & \multicolumn{2}{|c|}{} \\
\hline
\end{tabular}

\section{Stakeholder perspective}

Environment performances are influenced by stake holders such as governance, customers and suppliers. Caplice and Sheffi (1995) explain the importance of well-designed logistics performance measurement system and how it is aligned with relevant processes. Both Lu et al., (2007) and Zhu et al., (2008) highlight that companies become more environmentally due to 
the community pressure and the consumer pressure. Bjorklund et. al., (2012) stated that the influence from stakeholder is an important aspect to measure the potential environment impact through environmental measurements.

\section{The Purpose of Measuring}

The fundamental issues in GSCM on PM are economic rent, managing the business better and understanding the business better and continuous improvement (Hevani et al., 2005). The practitioners can use various methods of scales to measure green supply chain management for continuous improvement and implementation of green supply chain management for the measuring purposes (Zhu et al., 2008). The purpose of measuring in the study clear and provide support for future design of the supply chain (Bjorklund et. al., 2012)

\section{Managerial level of measuring}

Vanteddu et al., (2006) Gunasekeran et al., (2004) explained about the three managerial levels of strategic, managerial and operational. Vertical integration of management decision ant strategic level and tactical decision of planning at middle level management and operational decision made my lower level management. (Bjorklund et. al., 2012) highlight the necessity of the strategic management level involvement to the reverse supply chain.

\section{Measuring across supply chain management}

The importance of horizontally integrated management system includes all activities, functions and processes related to the entire supply chain operation (Caplice and Sheffi (1995).

\section{Combination of measurement}

Gunasekeran et al., (2004) and Caplice and Sheffi (1995) explain the importance of financial and nonfinancial performance measures which most companies failed to apply. Both environmental aspects and economical aspects are simultaneously proving the win-win situation in the measurement system (Bjorklund et. al., 2012).
Lee et al., (2012), study is to explore green supply chain management practices and their relationship with organizational performance of small and medium enterprises who servers to large customer firms in the Electronic Industry. The findings shows that there was a direct link between GSCM implementation and business performance.

Shi \& Koh (2012) publish a paper to conceptualise a structural model of natural resource based green supply chain management and its relationship with an indication of cause and effect to relevant performance measures and drivers. They identified that causal relationship have been formulated through both existing empirical findings and by identifying theoretical propositions.

Seman et al., (2012) their study is based on an overview of the development of GSCM literature in a developed countries and developing countries. They conclude that some studies in the literature discuss the GSCM implementation, GSCM drivers, practices and performance all over the world but less research about the GSCM implementation and adoption in Malaysia.

Lakshmimeera \& Palanisamy (2013) consolidated a paper on a Conceptual Framework on Green Supply Chain Management practices for Indian Manufacturing industry. They conclude that Green Supply Chain management Practices can improve competitiveness and environmental performance leading to sustainability.

Chien (2014), explain the influences of green supply chain management practices

on organizational sustainable performance and found that Green Supply Chain Management practiced by Taiwan Electrical and Electronic manufacturers and will positively affect the economic, environmental, and social performances.

Diab et al., (2014) tested the impact of Green Supply Chain Management Practices on Organizational performance and their study based on Jordanian Nutrition Industries and selected six companies specialised in food industry. Results of the study shown that there was an impact on green supply chain management practices on organizational performance 
which are environmental performance, financial performance and operational performance.

Muma et al., (2014) investigate the effect of Green Supply Chain Management on environmental Performance among tea processing firms in Kericho County. Based on the

Findings, study confirm that there is a positive relationship between Green supply chain management practices, green purchasing, green manufacturing, Green distribution, Green marketing and reverse logistics and environmental performance.

Al Khattb et al., (2015) tested the impact of the green supply chain management on environmental-based marketing performance. Their selected five Jordan companies and distributed 125 questionnaires. It has proven that Green Supply chain management such as Internal environmental management, Green Purchasing, Green Information systems, Cooperation with customers, Eco-design and packaging, and investment recovery practices affected the environmental marketing performance.

Cosimato. \& Trosi. (2015) investigated how logistics organisations try to face the recent ecological challenges and the role of emerging green technologies play in making them green and competitive. Their findings in DHL case study evidence that logistics innovation is based on emerging technologies which are more related to the development of sustainable and environment-friendly approach.

Chiu. \& Hsieh (2015) tested the green supply chain practices in Taiwan Resturant and firm performances. GSCM practices and firm performances are mediating with green capability and their research concluded that Green Practices in restaurants in Taiwan have an indirect effect on firm performance through green capability and highlighted that if it is a higher degree it will contribute to the organisational performance.

Chin et al., (2015) discussed a conceptual model which are related to Relational View Theory originated by Dyer and Singh (1998) linking with GSCM practices, Environmental Collaboration and sustainability performance. The GSCM practices are conceptualized with Green procurement, Green manufacturing, green distribution and green logistics. The sustainability performance is measured through Economic, Environmental and Social performance with the moderating effect of Environmental Collaboration including trust, loyalty, fairness in negotiation, commitment.

Tomar \&Oza (2015) study relationship of Green supply chain management practices and organizational performance and selected ISO certified companies in Gujarat Region. The study shows that all green practices are not followed by the companies the available resources and capabilities are vary towards that GSCM implementation.

\section{Conclusion}

Through this study the concept of Green Supply Chain Management was critically reviewed to identify the different dimensions of it. Although it is a relatively new aspect of supply chain management, the green supply chain management is an emerging trend to ensure the sustainability of the organisational supply chains. However, the mostly prominent dimensions of green supply chain management through the reviewed literature were Green Procurement, Green Design and Manufacturing, Green Distribution, Reverse Logistics were the identified dimensions of Green Supply Chain Management.

\section{References}

AI Khattab , S.A., Abu-Rumman, A.H. and Massad M.M (2015) The impact of the Green Supply Chain Management on Environmental-based Marketing Performance. Journal of Service Science and Management,

http://dx.doi.org/10.4236/jssm.2015.84059

Bjorklund M. et al.,2012, Performance measurement in the greening of supply chains. Doi:10.1108/13598541211212186

Caplice,C and Sheffi, Y. (1995), "A review and evaluation of logistics performance measurement system", The International Journal of Logistics Management, Vol.19 No:2, pp.389-54.

Chin T.A, Tat H.H., Sulaiman Z 2015 online paper on $12^{\text {th }}$ Global Conference on Sustainable Manufacturing doi:10.1016/j.procir.2014.07.035

Carter, C.R. and Ellram, L.M. (1998). Reverse logistics: a review of the literature and framework for 
future investigation. Journal of Business Logistics, $19,85-102$.

Chien K.M (2014), "Influences of Green Supply Chain Management Practices on Organizational Sustainable Performance" International Journal of Environmental Monitoring and Protection. Vol. 1, No.1,2014 pp 12-23

Chiu Zhi-Jun and Haiesh Chen (2016) Sustainability 2016, 8,42; doi:10.3390/su8010042

Cosimato S and Troisi O (2015), "Green Supply Chain Management" Practices and tools for logistics competitiveness and sustainability" The TQM Journal, Vol.27 No:2, 2015. DOI 10.1108/TQM-012015-0007

Diab M.S, Al-Bourini F.A and Abu-Rumman A.H (2015), "The Impact of Green Supply Chain Management Practices on Organizational Performance: A Study of Jordanian Food Industries" Journal of Management and sustainability; Vol.5, No:1,(2015) Doi:10.5539/jms.v5n 1p149

Dyer JH, Singh H. The relational view: Corporate strategy and sources of inter-organizational Competitive advantage. Academy of Management Review 1998; 23:660-679

Esty, D. and Winston, A. (2006), Green to Gold: How Smart Companies Use environmental strategy to innovate, Create Value, and Build Competitive Advantage, Yale University Press, New Hven, CT.

Green, K.W. Jr and Inman, R.A. (2005), "Using a just-in-tile selling strategy to strengthen supply chain linkages", International Journal of Production Research, Vol. 43 No:16, pp.3437-53.

Gunasekeran, A., Patel, C. and McGaughey, R.E.(2004), "A framework for supply chain performance measurement “, International Journal of Production Economics, Vol. 87 No, 3, pp.333-47.

Hansmann, K.W. and Claudia, K. (2001), "Environmental management policies", in Sakis,J. (Ed), Green Manufacturing and Operations: from Design to Delivery and Back, Greenleaf Publishing, Sheffield, PP. 192-204.

Hervani, A. \& Helms, M. \& Sakis, J. (2005) "Performance measurement for green supply chain management" Benchmarking: An International Journal Vol.12 No.4, pp. 330-353.

Kenneth W. Green fr et al., 2012, Green supply chain management practices": impact on performance. Supply Chain Management: An International Journal 17/3 (2012) 290-305.

Lewis, H. and Gretsakis, J. (2001), Design + Environment: A Global Guide to Designing Greener Goods, Greenleaf Publishing, Sheffield.

Lee M.S. et al., "Green Supply Chain Management and Organizational Performance"
Industrial Management \& Data Systems Vol.112 No.8, 2012 pp.1148-1180 Emerald publications Limited

Lee,J.J.,O’Callaghan, P. and Allen,D.(1995). Critical review of life cycle analysis and assessment techniques and their application to commercial activities. Conservation and recycling, 13, 37-56

Linhoff, B.(1993)Pinch analysis-a state-of-the art overview. Transaction of Chemical Engineering, 71, 503-522

Lee M.S, Kim, T.S and Choi,D,(2012). "Green supply chain management and organizational performance" Industrial Management and Data Systems Vol. 112 No. 8, 2012 pp.1148-1180.

Madu,C.N..,Kuei,C.and Madu,I.E.(2002). A hierarchic metric approach for integration of

Green issues in manufacturing: a paper recycling application. Journal of Environmental Management, 64, 261-272.

Meera B.L.L,and Chitramani P, (2016), "Casual Effect of Between Lean and Green Supply Chain Management Practices on Environmental Performance of Manufacturing Firms" International Journal of Management \& Business Studies Vol.6, Issue 2, ISSN:2231-2463

Muma O.B, Nyaoga R.B, Matwere, B.R, and Nyambega E (2014), Green Supply Chain Management and Environmental Performance among Tea Processing Firms in Kericho County-Kenya". International Journal of Economics, Finance and Management Sciences. Vol.2, No:5, 2014,pp.270276, doi:10.11648/j.ijefm.20140205.11

Shultz,C.J., \& Holbrook, M.B. (1999). Marketing and Tragedy of The Commons: A synthesis, Commentary and analysis for Action, Journal of Public Policy and Marketing, 18(2), 218-229

Sarkis, J. (1995), Supply chain Management and environmentally conscious design and manufacturing. International Journal of Environmentally conscious design and manufacturing, 4(2), pg.43-52

Sarkis, J (1995), "Manufacturing strategy and environmental consciousness", Technovation, Vol. 15 No.2, pp. 79-97.

Sarkis, J. (2001), "Manufacturing's role in corporate environmental sustainability: concerns for the new millennium", International Journal of Operations and Production Management Vol. 21 Nos 5/6, pp. 66685.

Sarkis, J (2011), “A boundaries and flows perspective of green supply chain management"

Supply Chain Management: An International Journal 17/2 (2012) 202-216.

Srivastava S.K.(2007), Green Supply Chain Management: A state-of-the-art literature review, 
International Journal of Management Review, volume 9 issue 1 pp.53-80 doi:10.1111/j.14682370.2007.00202.x

Shi G.V., Lenny Koh S.C, Balwin J, Cucchiella,F (2012) Natural resource based green supply chain management .DOI 10.1108/1359854121121212203.

Seman N.A.A, Zakuan,N. JusohA and Shoki M. Green Supply Chain Management: A Revie

W and Research Direction

DOI:10.5121/ijmvsc.2012.3101

Tomar A,and Oza H.(2015), "Green Supply Chain Management Practices Implementation and Effect on Organizational Performance of ISO14001 Certified Manufacturing Companies of India" Abhinav International Monthly Refereed Journal of Research in Management \& Technology Volume 4, Issue 9, online ISSN-2320-0073
Van Hock, R.I. and Erasmus (2000), "From reversed logistics to green supply chains", Logistics Solutions, No.2, pp. 28-33.

Vanteddu, G.,Chinnam, R.B. and Yang, K.(2006), A performance comparison tool for supply chain management", International Journal of Production economics, Vol.111 No:4, pp 342-56

Zhu, Q. Sakis, J. Cordeiro, J. Lai, K.L.(2008) "Green supply chain management implications for closing the loop", Journal of transportation Research Part E 44, pp. 1-18

Zhu, Q.,Sakis, J and Lai, K (2008a), “Confirmation of a measurement model for green supply chain management practices implementation", International Journal of Production Economics, Vol. 111 No.2, pp. 261-73. 